\title{
Reliability of ice-core science: historical insights
}

\author{
Richard B. ALLEY \\ Department of Geosciences, and Earth and Environmental Systems Institute, The Pennsylvania State University, \\ 517 Deike Building, University Park, Pennsylvania 16802-2711, USA \\ E-mail: rba6@psu.edu
}

\begin{abstract}
Ice cores are remarkably faithful recorders of past climate, providing multiply duplicated reconstructions with small and quantifiable uncertainties. Ice-core reconstructions in general do not rely on assumed quantitative time-invariance of empirical calibrations between climate and sedimentary characteristics, but instead rely on assuming little more than the constancy of physical law over time. The history of some of the discoveries that allow these ice-core climatic reconstructions is instructive for students, citizens and policymakers. Much important ice-core science was published in the Journal of Glaciology and the Annals of Glaciology, with scientific impacts much larger than indicated by mere citation counts.
\end{abstract}

\section{MOTIVATION}

The Journal of Glaciology is a disciplinary or archival journal. More often than not, papers with the highest impact and highest press coverage are published elsewhere, but the fundamental science underlying those 'news' papers is published in the Journal or the Annals of Glaciology. The value of such disciplinary journals is too often underestimated; they represent an absolutely essential part of science.

Based on anecdotal evidence and personal experience, I doubt that the public has ever had a deep and broad understanding of the large number and great strength of the procedures we scientists use to make it as hard as possible for us to fool ourselves. However, I believe that over my career there has been a decrease in the number of people willing to assume that we have such procedures and that we do due diligence implementing them.

Consider one example of many. Recently, I was quoted in public discussing how ice-shelf loss from warming removes 'frictional' buttressing, allowing faster flow of non-floating ice streams contributing to sea-level rise. A correspondent then suggested that I should go back to school and learn what 'to float' means, arguing that melting of an ice cube in a glass does not raise the water level, so melting of an ice shelf cannot possibly raise sea level, so I must be deeply confused or worse. In my experience, in previous decades the correspondent might have assumed that flotation was part of my education, and thus might have paid attention at least long enough to hear the explanation about friction and ice streams, rather than immediately assuming that I must be wrong or mendacious.

Among many implications of this shift in the response of at least some members of the public to science, I believe that all of us in the scientific community, with special emphasis on our students, must improve our ability and willingness to explain: (1) the scientific basis of our particular public statements; and (2) the basis of science - testing hypotheses against nature, peer-reviewed publication with sufficient details to allow replication, actual replication, and unpaid public assessment of science as practiced by the national academies of science or the Intergovernmental Panel on Climate Change (IPCC). Additional elements of our science are also worth communicating, including peer-reviewed funding, long apprenticeships typically involving more than one advisor, interlaboratory comparisons, international collaboration and our practice of giving our biggest awards and honors to those who demonstrate the shortcomings of their elders.

Students may find it enjoyable to learn much of this information by considering history, and 200 issues of the Journal of Glaciology over 60 years offer an excellent opportunity to review some of that history. I was asked here to review some aspects of ice-core science. Consistent with other subdisciplines covered by the Journal, ice-core science is broadly important, underlying key parts of the wider science of climate change and figuring prominently in assessments such as the IPCC reports. Like those other subdisciplines, the quality of ice-core science is outstanding. Important parts of that history have been written in disciplinary journals such as the Journal and Annals of Glaciology, including the two Annals volumes dedicated to ice cores (Oeschger, 1988; Wolff, 2002; with a third planned for the 2012 International Partnerships in Ice-Core Science meeting). Here, after brief mention of some general ice-core history, I will highlight a few of the many reasons why icecore results are so highly reliable through review of some of the historically key advances. My presentation is meant to be informative rather than exhaustive.

\section{ICE CORING}

The fascinating history of ice-core science is being written, if slowly. The recent contributions by Dansgaard (2005) and Langway (2008) are especially relevant. The interested reader may enjoy exploring the web resources at the American Institute of Physics (http://www.aip.org/history/ sloan/icedrill/index.html). (Additional historical insights by one of the pioneers were originally scheduled for this volume, but outgrew the venue and are being prepared for publication elsewhere.)

Ice 'coring' is often traced back to Ernst Sorge, who overwintered at Eismitte in Greenland during the 1930/31 expedition led by Alfred Wegener (Langway, 2008). There, Sorge excavated by hand a $15 \mathrm{~m}$ deep snow pit without falling in and damaging himself. He identified annual layers, measured densities and collected the data that led to Sorge's law, calculating the densification rate from the modern depth-density profile and accumulation rate by assuming steady state (Bader, 1954). 


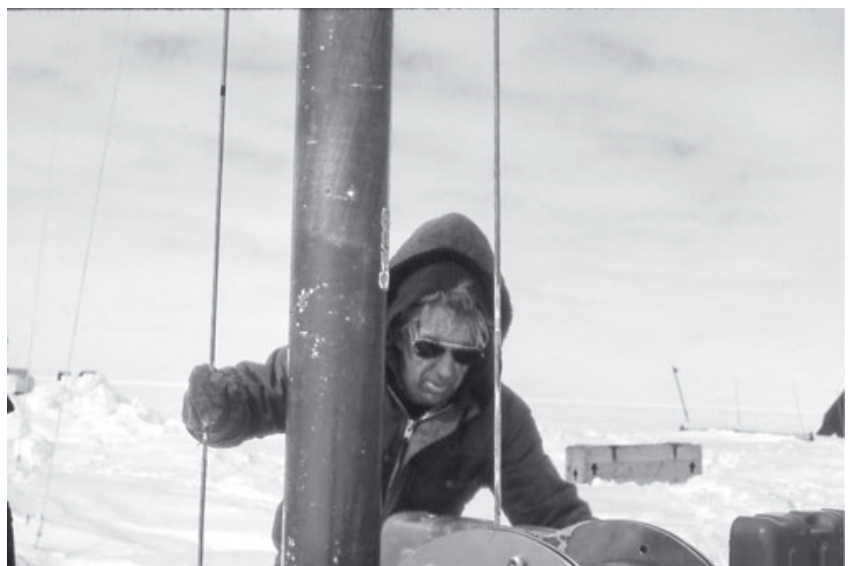

Fig. 1. The late Bruce Koci, one of the unsung heroes of ice-core science, recovering a $\sim 100 \mathrm{~m}$ core at site A, Greenland, 1985. Photograph by R. Alley.

As reported by Langway (2008), subsequent notable efforts in about 1950 led to ice coring to $\sim 100 \mathrm{~m}$ by the Norwegian-British-Swedish Antarctic Expedition along the Dronning Maud Land coast, by the Juneau Ice Field Research Project on Taku Glacier in Alaska and by the Expéditions Polaires Françaises at Camp VI and Station Central in Greenland. Langway (2008, p. 7) noted that all three involved 'exhaustive efforts and marginal success' in recovering high-quality core rapidly. I have been involved in ice-core science in some capacity for over 30 years and have heard many people say some version of 'This should be easy' - but it isn't! The successes achieved are testament to triumphs in science, engineering, organization, funding, international collaboration and more, by people who combined brilliance with remarkable tenacity (Fig. 1).

Corings through the Greenland ice sheet at Camp Century by 1966 and through the Antarctic ice sheet at Byrd Station in 1968 were highly successful and contributed important scientific results. Numerous people made these triumphs possible: H. Ueda, D. Garfield, C. Langway and Seligman Crystal recipients A.J. Gow and L. Hansen are among those deserving special mention. $\mathrm{H}$. Bader, also a recipient of the Seligman Crystal, was instrumental in the deep drilling. The contributions of numerous other ice-core pioneers, including Seligman laureates W. Dansgaard, H. Oeschger, S.J. Johnsen, C.J. Lorius, L.G. Thompson and P.A. Mayewski, deserve further attention.

Many of these contributions were made as part of a string of large and highly successful deep coring projects. In Greenland (Fig. 2), these include GRIP (e.g. Johnsen and others, 1992), GISP2 (e.g. Taylor and others, 1993) and NorthGRIP (e.g. NorthGRIP Members, 2004); in Antarctica, these include Vostok (e.g. Petit and others, 1999), EPICA Dome C (e.g. EPICA Community Members, 2004), EPICA Dronning Maud Land (e.g. EPICA Community Members, 2006), WAISCORES (e.g. Severinghaus and others, 2009) and Dome F (e.g. Kawamura and others, 2007). These projects have demonstrated the tight coupling between climate and $\mathrm{CO}_{2}$ over 800000 years, the hugely anomalous nature of the recent rise in $\mathrm{CO}_{2}$ compared with natural shifts over that time, the reality of abrupt climate change and the global reach of its effects, and so much more. Such results are among the most important parts of climate science, and surely deserve a more thorough historical treatment.

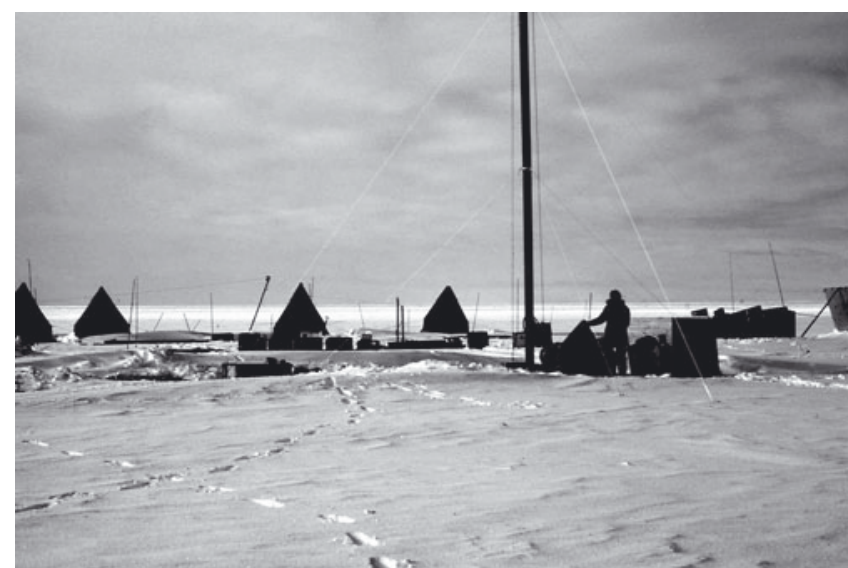

Fig. 2. Drill camp at site A, Greenland, 1985. The cold central regions of Greenland are ideal for borehole thermometry and other techniques of ice-core paleoclimatology. Site A was studied by European and US teams as part of the site-selection activities for GRIP and GISP2. Photograph by R. Alley.

Here, however, I wish to focus on the reliability of the paleoclimatic records, rather than on the heroics of obtaining them or their immense value. Reliability was a main focus of those Seligman laureates and of many other researchers. Ice-core data enjoy a special place in discussions of paleoclimatology by providing especially reliable multi-parameter reconstructions with small quantifiable uncertainties. The small uncertainties in turn are achieved by developing indicators that are more actualistic than uniformitarian, as discussed next.

\section{THE ICE-CORE HISTORY OF LOCAL TEMPERATURE AND SNOWFALL}

Geologists have often distinguished between actualism, the assumption of constancy of physical law, and uniformitarianism, the assumption of near-constancy of rates or intensities of processes over time (e.g. Bates and Jackson, 1980). There is no sharp line separating these, but we can usually tell where we are on the continuum between them.

Consider paleothermometry from tree-ring width, which is an indicator toward the uniformitarian end of the spectrum (e.g. see Bradley, 1999). In cold places, a tree may grow more rapidly in a warmer year, for biologically sensible reasons. A regression of recent growth rates against recent temperatures will calibrate the relationship. Normally, some data will be held out of the calibration and used to test the relation. If the test is successful, the calibration can be applied to a longer history of ring widths to reconstruct temperatures prior to instrumental data, assuming that the calibration has remained unchanged over time.

Tree growth may respond to changes in many other factors, however, including moisture availability, nutrient supply, weather extremes, seasonality of climate, atmospheric composition, pests, competition including introduced species, pollutants, and much more. It is not hard to think of many ways in which a change in tree growth could deviate from the recent instrumental calibration. Of course, the scientists working on tree rings are very well aware of this and are careful in site selection, searching for other causes, and replicating in many places. Comparison of several 
independent indicators in a region is especially valuable. For example, agreement among tree rings, pollen spectra, chironomids and other archives makes it more likely that the desired climate signal is being extracted. Still, 'maybe something in addition to temperature changed' is a hard argument to refute.

The $\delta^{18} \mathrm{O}$ or $\delta \mathrm{D}$ of ice-core ice is another indicator on the uniformitarian end of the spectrum. The physical basis for a dependence on temperature is very strong, surveys over short times and over space show good correlations, and atmospheric models of varying complexity tend to confirm this behavior (e.g. see Jouzel and others, 1997; Alley and Cuffey, 2001). As with tree rings, reconstructions of climate with very high time resolution are possible. However, changing source location or source temperature for the moisture in snowfall, seasonality of accumulation and other processes can also shift those isotopic ratios, so interpretation of past temperature from isotopic ratios alone includes possible systematic errors that may be difficult to evaluate but large compared with measurement or calibration errors.

Borehole temperatures offer a more-nearly actualistic indicator: the ice $100 \mathrm{~m}$ down in Greenland has not finished warming from the Little Ice Age, the ice halfway to the bed has not finished warming from the Ice Age, and these temperature anomalies are strong indications of the former cold. Heat flow is a well-understood physical process, and the effects of ice flow are often not unduly complicating (e.g. Robin, 1955). Ice-core observations reveal clearly whether significant melting has occurred and whether widespread crevassing occurred (e.g. Voigt and others, 2003); in their absence, air temperatures and near-surface snow temperatures are similar. The possibility of using the borehole temperatures in hypothesis-testing about past climate changes has long been clear and compelling (Johnsen, 1977). A major difficulty is the low time resolution of the borehole record, together with the non-uniqueness of mathematical inversions to learn the past surface-temperature history from the modern temperature-depth profile.

One of the seminal papers in paleoclimatology, Paterson and Clarke (1978), showed a novel path to solving the challenge of interpreting temperature profiles. They combined borehole and oxygen-isotopic paleothermometry, adjusting the relation between $\delta^{18} \mathrm{O}$ and temperature to obtain an optimal fit of modeled to measured temperaturedepth profiles; the history of $\delta^{18} \mathrm{O}$ provided the time schedule and relative amplitude for climate changes, and the borehole thermometry provided the absolute calibration. The Devon Island (Canada) sites they studied experienced notable melting, and the effects of that melting on the temperature profile proved to be more important than the detailed calibration of the isotopic record. Paterson and Clarke (1978) thus noted, 'this test shows that the Devon Island boreholes are unsuitable for testing the applicability of any particular value of $b$ [the intercept in the assumed linear relation between $\delta^{18} \mathrm{O}$ and temperature]. This is because variations in the latent heat released by refreezing of meltwater are much more important than variations in surface temperature in determining the temperature distribution. Such a test should be made at a place where melting is negligible' (p. 629-630).

Clearly, central Greenland satisfies the criterion suggested by Paterson and Clarke (1978). Cuffey and others (1992, 1994, 1995) and Johnsen and others (1995) applied the Paterson-Clarke technique to the GISP2 and GRIP sites, respectively. They showed successfully that calibration of the modern isotopic ratios using spatial covariation can lead to twofold or larger errors, that the uniformitarian hypothesis introduces much larger errors than indicated by a formal statistical analysis of the calibration, and thus that factors in addition to temperature change were recorded in the isotopic record. (Changes in seasonality of precipitation seem to have been especially important; e.g. Fawcett and others, 1997.)

It is instructive to note that when I was writing this (21 October 2010), the ISI Web of Science listed just 23 citations of the seminal paper of Paterson and Clarke suggesting the idea of joint interpretation of the isotopic and borehole-temperature records. (Ten of those citations were from papers published in the Journal of Glaciology or Annals of Glaciology.) An additional 75 citations were indexed to the Cuffey and others (1994) paper in the Journal of Glaciology reintroducing the technique in the context of Greenland (seven of those citations were from papers in the Journal or Annals of Glaciology; this put the Cuffey and others paper as one of the more highly cited in Journal history). However, 249 citations were indexed to the Cuffey and others (1995) paper and 304 to the Johnsen and others (1995) paper demonstrating just how cold the Ice Age was in Greenland (with just over 7\% of those from the Journal or Annals of Glaciology). This demonstrates that citation counts do not provide a complete picture of the progress of science. (As a historical note, the collaboration of Stan Paterson, now Honorary Member of the International Glaciological Society, and Garry Clarke, uniquely holding all three awards of Honorary Membership, Richardson Medal and Seligman Crystal, was already a successful one at the time Stan invited Garry to help solve the problem of Devon Island borehole temperatures. Kurt Cuffey, who applied the Paterson-Clarke techniques successfully, has carried on the massive work launched by Stan with the Cuffey and Paterson (2010) fourth edition of The physics of glaciers.)

Various other techniques for inversion of borehole temperature profiles to determine past surface-temperature history avoid reliance on the isotopic ratios. These include control methods (MacAyeal and others, 1991) and Monte Carlo techniques (Dahl-Jensen and others, 1998). Agreement among the different techniques increases confidence in the results.

Since borehole thermometry relies on well-understood physical processes with minimal use of assumed constancy of calibrations, the climatic reconstructions are especially reliable. Joint interpretation of borehole temperatures and isotopic ratios demonstrates that the higher-frequency isotopic oscillations contain temperature information, but suggests that the calibration of the isotopic thermometer may vary with time or with the frequency of the climate changes.

Testing this frequency dependence or time dependence of the isotopic temperature calibration became possible with a different set of tools based on gas isotopic fractionation in firn. Again, the reconstructions rely much more on constancy of physical law than on extrapolation of modern calibrations. A useful starting point for the history of this breakthrough is the discovery of gravitational fractionation of gases in firn by Michael Bender, Todd Sowers and Jakob Schwander (Craig and others, 1988; Schwander, 1989; Sowers and others, 1989). This experimental demonstration of the strictly limited extent of wind mixing of firn gases opens a wealth of additional actualistic paleoclimatic techniques, some of which are described below. 
The other key step was the discovery by Jeff Severinghaus of thermal diffusion in firn. A rapid temperature change at the surface causes a temperature gradient down the firn column, producing very slight separation of gases with the heavy species moving to the cold end within a few years (Severinghaus and others, 1998). The effects of thermal diffusion and gravitation can be evaluated separately if multiple species (such as nitrogen and argon isotopes) are used, because gravitational separation depends solely on mass difference but thermal fractionation is not rigidly massdependent and varies with the element involved. The atmospheric residence times of argon and nitrogen are so long that atmospheric composition can be considered constant over the duration of the ice-core record. Thus, very slight compositional differences between the air trapped in bubbles and the free atmosphere reveal the temperature difference across the thickness of the firn.

Since the time for the physical temperature of ice at the bubble-trapping depth to equilibrate with a new surface temperature in central regions of ice sheets is many times longer than the time for diffusive equilibration of the gases in the firn, anomalous gas is trapped for many decades after a surface-temperature change, with the size of the anomaly revealing the temperature difference across the firn (which equals the size of the abrupt change, if the change was sufficiently fast). The position of the gas isotopic anomaly in an ice core reveals where the bubbles were being trapped when the surface-temperature change occurred.

Direct use of the gas isotopic anomalies to learn the temperature difference across the firn required precise laboratory calibration of the behavior of argon and nitrogen isotopes in a temperature gradient, and was achieved by Severinghaus and Brook (1999) and Grachev and Severinghaus (2003a,b). In Severinghaus and others (1998), the absolute temperature during the Younger Dryas in central Greenland was estimated from the number of years between the gas-phase and ice-phase indicators of the abrupt climate change that ended the Younger Dryas. Together with the accumulation rate (determined from the annual-layer thickness and an ice-flow model; Alley and others, 1993; Cuffey and Clow, 1997) and an empirically calibrated physical firndensification model dependent on temperature and accumulation rate (Herron and Langway, 1980), this age offset then provided an estimate of the absolute temperature averaged over the time that the firn was being buried to the bubble-trapping depth.

Note also that gravitational fractionation of firn air, which increases with the thickness of the firn in diffusive equilibrium, means that the thickness of the firn can be determined subject to a small uncertainty related to lack of detailed knowledge of the depth of the near-surface 'convective zone' associated with wind mixing. The thickness of the firn can be used, together with the accumulation rate and a firn densification model, to learn the absolute temperature averaged over the time during which the firn changed to ice. Advances in the ability to measure the isotopic composition of $\mathrm{Ar}$ and $\mathrm{N}_{2}$ in ice cores have allowed identification of even relatively small surface-temperature changes (both warming and cooling) and their relation to changes in other gas species $\left(\mathrm{CO}_{2}\right.$ and $\left.\mathrm{CH}_{4}\right)$ (Caillon and others, 2003a,b; Grachev and others, 2007).

Yet another physically based indicator towards the actualistic end of the spectrum is provided by the number density of bubbles. Firn appears to be geometrically self-similar or nearly so (Gow, 1968), such that an increase in crystal size at the bubble-trapping depth will produce fewer bigger bubbles without changing the total amount of trapped air. Crystal size at the bubble-trapping depth increases with the crystal growth rate and thus with temperature, and increases with the amount of time required to be buried to the bubble-trapping depth, which increases with decreasing temperature and decreasing accumulation rate. Bubble number density is preserved quantitatively for considerable times in ice, so bubble counts can be used with accumulation-rate estimates and a firn densification model to calculate temperature over the firnification time (Spencer and others, 2006).

Enough physically based thermometers are available that it should be possible to determine both accumulation rate and temperature from application of the full suite. However, for the more recent parts of the ice-core history (especially since the Last Glacial Maximum, but extending somewhat before), accumulation rate can be estimated accurately from the ice-core dating (see below) corrected for the effects of ice flow (e.g. Nye, 1963; Dansgaard and Johnsen, 1969; Alley and others, 1993; Cuffey and Clow, 1997) using knowledge from total gas content that the ice-sheet size has not changed hugely (Raynaud and others, 1997). The physically based indicators then yield the history of temperature. With increasing age, the uncertainty linked to ice-flow and accumulation-rate issues increases.

For the necessary age estimates, radiometric dating of ice is possible and may prove more valuable in the future. However, most dating now relies primarily on either annuallayer counting or correlation to accurately dated records from elsewhere.

Sorge recognized annual layers in his deep pit. Annuallayer counting has long been a mainstay of ice-core dating (Figs 3 and 4). Increasingly sensitive reproducible multiparameter ways of identifying annual layers have been developed (e.g. McConnell and others, 2002; Svensson and others, 2005; Rasmussen and others, 2006). For situations in which multiple measurements across suites of cores are possible, zero-error dating is achievable, just as for tree rings. However, this is expensive and very time-consuming for deep cores. Counting annual layers with errors of $\sim 1 \%$ or less is straightforward, but achieving and demonstrating zero-error counts over tens of millennia is much harder (Meese and others, 1997).

Increasingly, the ability to measure ages of paleoclimatic events in other archives (e.g. see Cai and others, 2006) and to correlate those events to the ice cores and between ice cores (e.g. see Blunier and Brook, 2001) means that certain points in ice cores can be dated with errors smaller than the $\sim 1 \%$ error from counting of ice-core layers. In many ways, ice cores are the 'rosetta stones' that allow development of a global network of accurately dated paleoclimatic records using the best ages determined anywhere on the planet. This is because the ice cores show that many abrupt climate changes have been very tightly synchronous across broad regions in both high and low latitudes. Synchronous changes in indicators such as methane, $\delta^{18} \mathrm{O}$ of $\mathrm{O}_{2}, \mathrm{~N}_{2} \mathrm{O}$ and others were recorded in the ice cores but were controlled by events far from the ice sheets, demonstrating the common age of the events with much less uncertainty than would be possible by comparing independently dated records from various places.

In turn, this suggests that annual-layer counts in ice cores will be used increasingly to interpolate between the fixed 


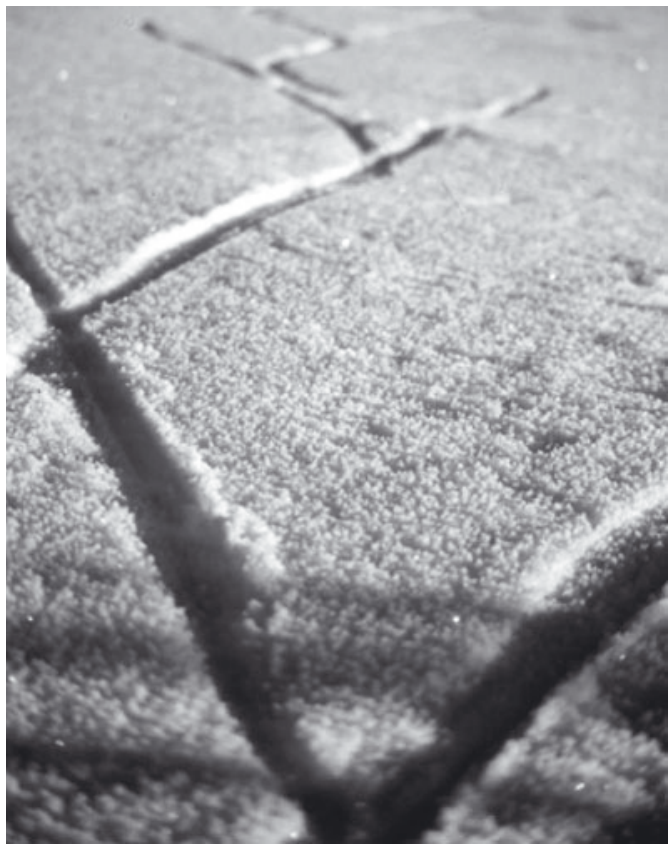

Fig. 3. Hoar frost with cross-country ski tracks, GISP2, central Greenland. Photograph by R. Alley.

points derived from those best ages for abrupt climate changes. The absolute layer counts in the ice cores will continue to provide a check on ages from elsewhere.

However, if ice-core annual-layer counts are used to interpolate between the fixed points dated by correlation, it becomes useful to be able to re-count quickly and accurately if the ages of the fixed points are adjusted by even better analyses. Such re-counting requires an adaptive scheme to identify optimally the correct number of years between the fixed points from the available data. To this end, development of 'auto-pickers' using digital data may offer the best way forward (see Taylor and others, 2004), implementing a computerized technique (or suite of techniques) with tuneable parameters that can be optimized to give an objective counting match to independent time markers.

Taken together, for cores from regions with little melting, ice-core science provides ages through layer counting or correlations as accurately as for any other archive, and much more accurately than for most. Furthermore, the history of snow accumulation rate and temperature can be determined with little uncertainty, relying primarily on physics rather than correlations, with multiple redundancy and small quantifiable uncertainties. This provides what I believe are the most reliable paleoclimatic records on Earth extending back at least a few tens of thousands of years. This success is based heavily on fundamental glaciological science, including studies of temperature in ice sheets, flow deformation and firn densification.

\section{A FEW RESULTS ON TRAPPED GASES}

Many other aspects of ice-core science are especially well supported by fundamental science demonstrating the high reliability of the results. In this short historical review, I cannot begin to do justice to the many contributions in the Journal of Glaciology and elsewhere. In my experience, non-glaciologists are most interested in the ice-core records

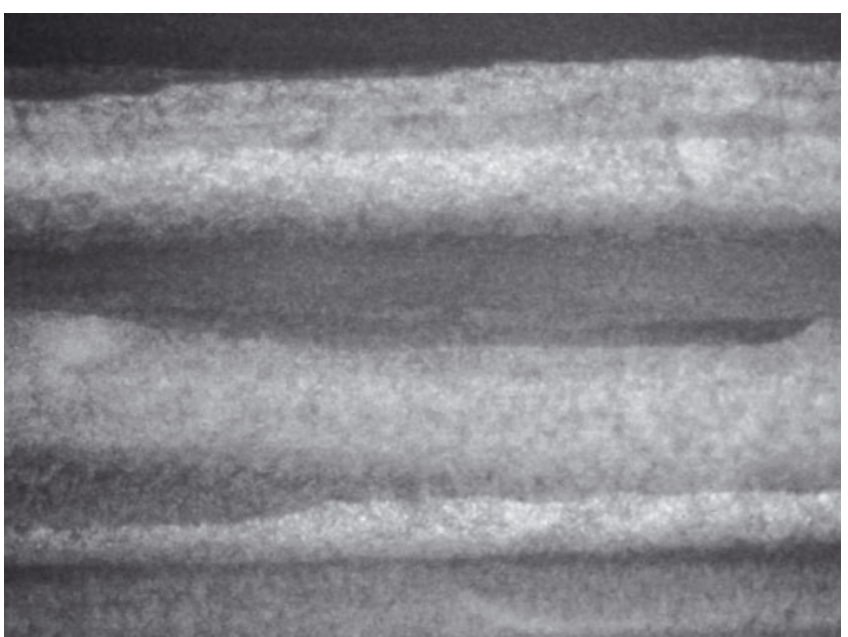

Fig. 4. Buried hoar frost (light layers), snow pit, GISP2. The photograph is about $10 \mathrm{~cm}$ high. Winter snow lacks the strong contrast shown here (e.g. Alley and others, 1990). Such differences have been used in annual-layer counting back to Sorge. Photograph by R. Alley.

of atmospheric composition, so I will provide a short discussion of the remarkably high reliability of these records based on physics. Please note that I am not trying to provide the most up-to-date references, but a historical perspective instead, to show how long we have known many of these things. With modern citation analysis, an interested reader can find out which more-recent papers have made use of these classic contributions, and thus work up to the present.

Some aspects of the history of atmospheric composition are very difficult to reconstruct in any way except by icecore measurements, such as the preindustrial history of methyl bromide (Saltzman and others, 2004). Other aspects, such as the $\mathrm{CO}_{2}$ concentration, can be estimated in many ways (e.g. see Jansen and others, 2007, section 6.3.1 and references therein). However, these tend to involve uniformitarian hypotheses to a considerable degree. Broad agreement among the various techniques is encouraging (Jansen and others, 2007, figure 6.1), but the uncertainties are notably larger than for ice-core records.

For ice cores, the approach is very actualistic. Samples of old air are archived in ice. Recovering and analyzing that air reveals the atmospheric composition in the past. Rather remarkably, this simple statement is a fairly accurate representation of the science, as discussed next.

At least part of the ice-core story of trace gases goes back to work by the late Norwegian Per Scholander on biological adaptation to cold conditions, conducted at the Office of Naval Research's Arctic Research Laboratory at Point Barrow, Alaska, shortly after World War II (see Shelesnyak, 1948a,b and the recent report by Elsner, 2005). Scholander's interest in the wintertime survival of organisms encased in ice led him to experiment on the diffusion of gases through ice, showing very slow rates and very low solubility (Scholander and others, 1953, section VI). (Many modern students would benefit from reading this paper to see how science is done, how much progress is possible, and the breadth and depth of knowledge required to make that progress.)

A follow-up study by Scholander involved analyzing ice retrieved from icebergs, presumably of Greenlandic origin, along the Labrador coast. As reported in Science: 'The rate of 
gas diffusion through ice is not more than 1/40000 to $1 / 70000$ as fast as it is through water (citation to Scholander and others, 1953). Considering this extremely slow rate, the relatively enormous diffusion distances in the glacier, and the large quantity of gases held under pressure in the ice, it would seem possible that gas trapped in the glacier would remain unchanged for millennia. Analysis of such gas could therefore give information about the atmospheric composition at the time the ice was formed.' (Scholander and others, 1956, p. 104)

Scholander and co-workers found that the bubbles contained pressurized air. Slight depletion of oxygen was reported, with the suggestion that this might reflect glacial/ interglacial changes, although a subsequent study (Coachman and others, 1958b) pointed to oxygen loss from bubbles through solution in small amounts of meltwater produced along the bubble surfaces. Scholander's research group also studied air and ${ }^{14} \mathrm{C}$ age of ice from near Thule, Greenland (Coachman and others, 1958a). Not surprisingly, Scholander published in the Journal of Glaciology, presenting results on the pressure and composition of bubbles in Greenland icebergs (Scholander and Nutt, 1960; Scholander and others, 1961). He then collaborated with the great Willi Dansgaard, using $\delta^{18} \mathrm{O}$ as well as ${ }^{14} \mathrm{C}$ to study ice from Greenland (Scholander and others, 1962; see also SchmidtNielsen, 1987).

The point of reviewing the contributions of Per Scholander is not simply to remember a great scientist, but to note that the analysis of ice-core gases started with fundamental physics: the low diffusion rate and solubility of gases in ice meant that the bubbles would preserve accurate records. Only after a range of background research did useful reconstructions of past atmospheres emerge.

The glaciological community greatly extended and improved the pioneering work of Scholander. A good review of some of the efforts expended to ensure reliability of the record is given by Raynaud and others (1993) (see also Raynaud and others, 2000), and I provide additional insights next.

The simplest, most compelling evidence demonstrating that Scholander accurately foresaw the utility of ice as a bottle for old air is provided empirically. For the key atmospheric trace gases, such as $\mathrm{CO}_{2}, \mathrm{CH}_{4}$ and $\mathrm{N}_{2} \mathrm{O}$, and for tens of thousands to hundreds of thousands of years we now have multiple records generated by different laboratories on different continents using cores from sites with different accumulation rates, temperatures and impurity loadings, often stored, handled and analyzed in different ways, yet yielding the same history within the combined analytical and dating uncertainties (e.g. see Jansen and others 2007, especially figure 6.4; Ahn and Brook, 2008). Furthermore, this record overlaps with the instrumental measurements of the free atmosphere, again with beautiful agreement (Neftel and others, 1985; Pearman and others, 1986). There is no plausible way that this agreement could be produced if there are significant problems with the entrapment, storage, recovery or reading of the atmospheric signal in the ice.

Furthermore, because bubbles are trapped at depth but snow is deposited at the surface, a climate change that affects the composition of the ice and of the air is recorded in different places along an ice core, with the offset depending on temperature and accumulation rate. The major changes in gas composition and ice composition are not in the same places in the key climate records from ice cores (e.g. Monnin and others, 2001); within the ice from which the main records are generated, the chemistry changes without affecting the gases, and the gases change without affecting the chemistry.

I could probably stop here, but it is instructive to look more deeply at the great number of underlying tests and the great range of supporting evidence, providing even stronger support for the high reliability of the ice-core record of atmospheric composition. This includes learning not only how to get the best record, but testing the limits of that record by finding out the conditions under which artifacts do occur, so that such conditions can be avoided. A few comments on these additional tests follow.

First, remarkable care goes into generating the records and ensuring their integrity.

The ice-core gas laboratories I have visited are impressive undertakings, with fanatical dedication to avoiding problems from contamination or leaks, and extensive use of laboratory standards and blind laboratory intercomparisons (e.g. Sowers and others, 1997).

Some analyses of old ice include searching for humanmade chlorofluorocarbons, which are ubiquitous in the environment today but absent from the preindustrial environment - any contamination must introduce these modern 'tracers', and absence of them shows that contamination has not been introduced (e.g. Etheridge and others, 1988; see also Aydin and others, 2010). Care is taken to monitor transport and storage conditions, and to quantify any post-recovery changes affecting the ice and contained gases (e.g. Bereiter and others, 2009).

The agreement between atmospheric measurements and concentrations in recently formed bubbles is very good (Etheridge and others, 1996; MacFarling and others, 2006). In addition, extensive sampling has been conducted in the firn, extracting air from specific layers, to track the complete transition from free atmosphere to ice-core bubbles in exquisite detail (e.g. Schwander and others, 1993; Bender and others, 1994).

Trapping of bubbles is not an instantaneous process, so any sample includes air with a range of ages. The width of that range - typically decades to centuries - has been studied carefully (Schwander and Stauffer, 1984). Short-lived events will be more evident in records from cores with a shorter trapping time, and indeed this is observed in specific cases (Spahni and others, 2003). If there were important short-lived climate events that had not been resolved by the ice cores, then markedly increasing variability with increasing time resolution would be evident at many points in the records. Interesting subtle effects may exist for some gases, but the good agreement among records shows that there are no major problems.

Rapid diffusion of gases in the ice would reduce the time resolution of records and give a false impression of smoothness, but this can be excluded with high confidence. The early work of Scholander, described above, shows that the science of ice-core gases started with the determination that diffusion is slow, and subsequent work supports this. A fascinating demonstration comes from clever use of a different potential problem: melt layers.

When melting occurs at the ice-sheet surface, the water typically refreezes into a bubble-poor layer that has an elevated concentration of $\mathrm{CO}_{2}$ due to its high solubility in water (Stauffer and others, 1985). Refrozen meltwater is 
readily apparent by inspection of bubbly ice, and indeed its occurrence can be used as a paleoclimatic indicator. Cores with extensive melting are avoided for studies of past atmospheric composition, and even small amounts of meltwater are problematic for highly soluble gases such as $\mathrm{CO}_{2}$.

However, the high $\mathrm{CO}_{2}$ concentration in the melt layers provides a tracer for diffusion. For sites with little melting, such as Siple Dome, Antarctica, the occurrence of meltwater is restricted to regions in or near the melt layer that ultimately forms (Das and Alley, 2005), and can be recognized by excess heavy noble gases as well as $\mathrm{CO}_{2}$. Measuring the modern width of the resulting $\mathrm{CO}_{2}$ anomaly compared with the original width from the visible melt layer provides an estimate of the diffusion. This rate is such that diffusion in very old, warm ice will have smoothed thin features, but the main results that have been presented to the public have not been significantly affected (Ahn and others, 2008).

At sufficiently great depth and pressure, the bubbles in ice cores disappear as solid air clathrates develop. The transformation is not instantaneous, and some gases preferentially fractionate into the solid phase or the gas phase in the zone where solid and gas coexist as dictated by the phase diagram for the particular gas (Ikeda and others, 1999). If an analytical technique is used that does not recover all of the gas in the solid phase in this region of coexisting clathrate and bubbles, then gases that preferentially enter the solid phase will appear anomalously depleted, while gases that preferentially remain in the gas phase will appear anomalously enriched. Indeed, such behavior is observed for $\mathrm{N}_{2} \mathrm{O}$, with reduced concentration measured using a dry extraction technique in the clathrateformation zone in comparison to a different core with the same-age ice completely above the zone of clathrate formation; however, comparisons outside this zone of clathrate formation do not find anomalies (Sowers and others, 2003; see also Lüthi and others, 2010).

Warming and increasing impurity levels both tend to favor biological activity or chemical reactions that could obscure the environmental record in ice cores. As noted above, the onset of melting is especially problematic, and any trace-gas record from ice with evidence of melting is viewed with extreme caution. Ice that is especially impure and warm, up to and including ice containing dead bugs, is found to contain highly anomalous gas concentrations reflective of processes in the ice (e.g. Souchez and others, 1995; Campen and others, 2003). Furthermore, small $\mathrm{CO}_{2}$ anomalies are observed in ice containing especially high levels of both carbonate dust and sulfuric acid, and likely resulting from $\mathrm{CO}_{2}$-liberating reactions between these in the ice (Stauffer and others, 1984; Delmas, 1993). However, as noted above, the trace-gas histories of atmospheric composition are independent of chemistry and temperature of ice for all colder, cleaner sites.

Taking all of these investigations together, fundamental scientific understanding indicates that trace-gas records from cold, clean sites on Greenland and especially Antarctica should provide accurate records of atmospheric composition with very little uncertainty. The published literature documents the great care taken by the relevant laboratories to achieve this goal, and the results show that different laboratories using different ice cores with different temperatures, accumulation rates and impurity loadings produce the same atmospheric histories, which agree with instrumental data. Combining these trace-gas results with the multiply duplicated determinations of age, temperature and accumulation rate allows especially reliable reconstructions of climate history, and hypothesis-testing regarding cause and effect in climate change.

More work remains to be done, and as increasingly precise measurements on increasingly small samples are developed, some of the issues discussed above may become more important. However, the main results of ice-core science have not been overturned despite being tested in many ways by many groups over many years and decades, and the main results are based strongly on physical understanding of relatively simple systems. Thus, these results are especially robust.

Knowledge of history, including the history of papers published in the Journal of Glaciology, shows that ice-core science is indeed reliable. The value of disciplinary journals such as the Journal of Glaciology is shown very clearly.

\section{ACKNOWLEDGEMENTS}

I thank Todd Sowers, Kurt Cuffey, Garry Clarke and Eric Wolff for helpful suggestions, and the US National Science Foundation for support under grants 0539578 and 0424589.

\section{REFERENCES}

Ahn, J. and E.J. Brook. 2008. Atmospheric $\mathrm{CO}_{2}$ and climate on millennial time scales during the last glacial period. Science, 322(5898), 83-85.

Ahn, J., M. Headly, M. Wahlen, E.J. Brook, P.A. Mayewski and K.C. Taylor. 2008. $\mathrm{CO}_{2}$ diffusion in polar ice: observations from naturally formed $\mathrm{CO}_{2}$ spikes in the Siple Dome (Antarctica) ice core. J. Glaciol., 54(187), 685-695.

Alley, R.B. and K.M. Cuffey. 2001. Oxygen- and hydrogen-isotopic ratios of water in precipitation: beyond paleothermometry. In Valley, J.W. and D.R. Cole, eds. Stable isotope geochemistry. Washington, DC, Mineralogical Society of America and Geochemical Society, 527-553. (Reviews in Mineralogy and Geochemistry 43.)

Alley, R.B., E.S. Saltzman, K.M. Cuffey and J.J. Fitzpatrick. 1990. Summertime formation of depth hoar in central Greenland. Geophys. Res. Lett., 17(12), 2393-2396.

Alley, R.B. and 10 others. 1993. Abrupt increase in Greenland snow accumulation at the end of the Younger Dryas event. Nature, 362(6420), 527-529.

Aydin, M. and 11 others. 2010. Post-coring entrapment of modern air in some shallow ice cores collected near the firn-ice transition: evidence from CFC-12 measurements in Antarctic firn air and ice cores. Atmos. Chem. Phys., 10(11), 5135-5144.

Bader, H. 1954. Sorge's Law of densification of snow on high polar glaciers. J. Glaciol., 2(15), 319-323.

Bates, R.L. and J.A. Jackson, eds. 1980. Glossary of geology. Alexandria, VA, American Geological Institute.

Bender, M.L., T. Sowers, J.M. Barnola and J. Chappellaz. 1994. Changes in the $\mathrm{O}_{2} / \mathrm{N}_{2}$ ratio of the atmosphere during recent decades reflected in the composition of air in the firn at Vostok Station, Antarctica. Geophys. Res. Lett., 21(3), 189-192.

Bereiter, B., J. Schwander, D. Lüthi and T.F. Stocker. 2009. Change in $\mathrm{CO}_{2}$ concentration and $\mathrm{O}_{2} / \mathrm{N}_{2}$ ratio in ice cores due to molecular diffusion. Geophys. Res. Lett., 36(5), L05703. (10.1029/2008GL03673.)

Blunier, T. and E.J. Brook. 2001. Timing of millennial-scale climate change in Antarctica and Greenland during the last glacial period. Science, 291(5501), 109-112.

Bradley, R.S. 1999. Paleoclimatology: reconstructing climates of the Quaternary. Second edition. San Diego, CA, Academic Press. (International Geophysics Series 58.) 
Cai, Y. and 7 others. 2006. High-resolution absolute-dated Indian Monsoon record between 53 and 36 ka from Xiaobailong Cave, southwestern China. Geology, 34(8), 621-624.

Caillon, N., J. Jouzel, J.P. Severinghaus, J. Chappellaz and T. Blunier. 2003a. A novel method to study the phase relationship between Antarctic and Greenland climate. Geophys. Res. Lett., 30(17), 1899. (10.1029/2003GL01783.)

Caillon, N., J.P. Severinghaus, J. Jouzel, J.-M. Barnola, J. Kang and V.Y. Lipenkov. 2003b. Timing of atmospheric $\mathrm{CO}_{2}$ and Antarctic temperature changes across Termination III. Science, 299(5613), 1728-1731.

Campen, R.K., T. Sowers and R.B. Alley. 2003. Evidence of microbial consortia metabolizing within a low-latitude mountain glacier. Geology, 31(3), 231-234.

Coachman, L.K., E. Hemmingsen, P.F. Scholander, T. Enns and H. de Vries. 1958a. Gases in glaciers. Science, 127(3309), 1288-1289.

Coachman, L.K., T. Enns and P.F. Scholander. 1958b. Gas loss from a temperate glacier. Tellus, 10(4), 493-495.

Craig, H., Y. Horibe and T. Sowers. 1988. Gravitational separation of gases and isotopes in polar ice caps. Science, 242(4886), $1675-1678$.

Cuffey, K.M. and G.D. Clow. 1997. Temperature, accumulation, and ice sheet elevation in central Greenland through the last deglacial transition. J. Geophys. Res., 102(C12), 26,383-26,396.

Cuffey, K.M. and W.S.B. Paterson. 2010. The physics of glaciers. Fourth edition. Oxford, Butterworth-Heinemann.

Cuffey, K.M., R.B. Alley, P.M. Grootes and S. Anandakrishnan. 1992. Toward using borehole temperatures to calibrate an isotopic paleothermometer in central Greenland. Global Planet. Change, 6(2-4), 265-268.

Cuffey, K.M., R.B. Alley, P.M. Grootes, J.M. Bolzan and S. Anandakrishnan. 1994. Calibration of the $\delta^{18} \mathrm{O}$ isotopic paleothermometer for central Greenland, using borehole temperatures. J. Glaciol., 40(135), 341-349.

Cuffey, K.M., G.D. Clow, R.B. Alley, M. Stuiver, E.D. Waddington and R.W. Saltus. 1995. Large Arctic temperature change at the Wisconsin-Holocene glacial transition. Science, 270(5235), 455-458.

Dahl-Jensen, D. and 6 others. 1998. Past temperatures directly from the Greenland ice sheet. Science, 282(5387), 268-271.

Dansgaard, W. 2005. Frozen annals: Greenland Ice Sheet research. Copenhagen, University of Copenhagen. Niels Bohr Institute.

Dansgaard, W. and S.J. Johnsen. 1969. A flow model and a time scale for the ice core from Camp Century, Greenland. J. Glaciol., 8(53), 215-223.

Das, S.B. and R.B. Alley. 2005. Characterization and formation of melt layers in polar snow: observations and experiments from West Antarctica. J. Glaciol., 51(173), 307-313.

Delmas, R.J. 1993. A natural artefact in Greenland ice-core $\mathrm{CO}_{2}$ measurements. Tellus, 45B(4), 391-396.

Elsner, R. 2005. Arctic files and fossil atmospheres: how new knowledge of ancient climates originated. Windswept: Q. Bull. Mt Washington Obs., 46(1), 26-28.

EPICA Community Members. 2004. Eight glacial cycles from an Antarctic ice core. Nature, 429(6992), 623-628.

EPICA Community Members. 2006. One-to-one coupling of glacial climate variability in Greenland and Antarctica. Nature, 444(7116), 195-198.

Etheridge, D.M., G.I. Pearman and F. de Silva. 1988. Atmospheric trace-gas variations as revealed by air trapped in an ice core from Law Dome, Antarctica. Ann. Glaciol., 10, 28-33.

Etheridge, D.M., L.P. Steele, R.L. Langenfelds, R.J. Francey, J.M. Barnola and V.I. Morgan. 1996. Natural and anthropogenic changes in atmospheric $\mathrm{CO}_{2}$ over the last 1000 years from air in Antarctic ice and firn. J. Geophys. Res., 101(D2), 4115-4128.

Fawcett, P.J., A.M. Agústsdóttir, R.B. Alley and C.A. Shuman. 1997. The Younger Dryas termination and North Atlantic deep water formation: insights from climate model simulations and Greenland ice core data. Paleoceanography, 12(1), 23-28.
Gow, A.J. 1968. Bubbles and bubble pressures in Antarctic glacier ice. J. Glaciol., 7(50), 167-182.

Grachev, A.M. and J.P. Severinghaus. 2003a. Determining the thermal diffusion factor for ${ }^{40} \mathrm{Ar} /{ }^{36} \mathrm{Ar}$ in air to aid paleoreconstruction of abrupt climate change. J. Phys. Chem. A, 107(23), 4236-4642.

Grachev, A.M. and J.P. Severinghaus. 2003b. Laboratory determination of thermal diffusion constants for ${ }^{29} \mathrm{~N}_{2} /{ }^{28} \mathrm{~N}_{2}$ in air at temperatures from -60 to $0^{\circ} \mathrm{C}$ for reconstruction of magnitudes of abrupt climate changes using the ice core fossil-air paleothermometer. Geochim. Cosmochim. Acta, 67(3), 345-360.

Grachev, A.M., E.J. Brook and J.P. Severinghaus. 2007. Abrupt changes in atmospheric methane at the MIS 5b-5a transition. Geophys. Res. Lett., 34(20), L20703. (10.1029/2007GL029799.)

Herron, M.M. and C.C. Langway, Jr. 1980. Firn densification: an empirical model. J. Glaciol., 25(93), 373-385.

Ikeda, T. and 7 others. 1999. Extreme fractionation of gases caused by formation of clathrate hydrates in Vostok Antarctic ice. Geophys. Res. Lett., 26(1), 91-94.

Jansen, E. and 15 others. 2007. Paleoclimate. In Solomon, S. and 7 others, eds. Climate change 2007: the physical science basis. Contribution of Working Group I to the Fourth Assessment Report of the Intergovernmental Panel on Climate Change. Cambridge, etc., Cambridge University Press.

Johnsen, S.J. 1977. Stable isotope profiles compared with temperature profiles in firn with historical temperature records. IAHS Publ. 118 (Symposium at Grenoble 1975 - Isotopes and Impurities in Snow and Ice), 388-392.

Johnsen, S.J. and 9 others. 1992. Irregular glacial interstadials recorded in a new Greenland ice core. Nature, 359(6393), $311-313$

Johnsen, S.J., D. Dahl-Jenson, W. Dansgaard and N. Gundestrup. 1995. Greenland paleotemperatures derived from GRIP bore hole temperatures and ice core isotope profiles. Tellus, 47B(5), 624-629.

Jouzel, J. and 12 others. 1997. Validity of the temperature reconstruction from water isotopes in ice cores. J. Geophys. Res., 102(C12), 26,471-26,487.

Kawamura, K. and 17 others. 2007. Northern Hemisphere forcing of climatic cycles in Antarctica over the past 360,000 years. Nature, 448(7156), 912-916.

Langway, C.C., Jr. 2008. The history of early polar ice cores. CRREL Tech. Rep. 08-1.

Lüthi, D. and 10 others. 2010. $\mathrm{CO}_{2}$ and $\mathrm{O}_{2} / \mathrm{N}_{2}$ variations in and just below the bubble-clathrate transformation zone of Antarctic ice cores. Earth Planet. Sci. Lett., 297(1-2), 226-233.

MacAyeal, D.R., J. Firestone and E. Waddington. 1991. Paleothermometry by control methods. J. Glaciol., 37(127), 326-338.

MacFarling, C. and 7 others. 2006. Law Dome $\mathrm{CO}_{2}, \mathrm{CH}_{4}$ and $\mathrm{N}_{2} \mathrm{O}$ ice core records extended to 2000 years BP. Geophys. Res. Lett., 33(14), L14810. (10.1029/2006GL026152.)

McConnell, J.R., G.W. Lamorey, S.W. Lambert and K.C. Taylor. 2002. Continuous ice-core chemical analyses using inductively coupled plasma mass spectrometry. Environ. Sci. Technol., 36(1), 7-11.

Meese, D.A. and 8 others. 1997. The Greenland Ice Sheet Project 2 depth-age scale: methods and results. J. Geophys. Res., 102(C12), 26,411-26,423.

Monnin, E. and 7 others. 2001. Atmospheric $\mathrm{CO}_{2}$ concentrations over the last glacial termination. Science, 291(5501), 112-114.

Neftel, A., E. Moor, H. Oeschger and B. Stauffer. 1985. Evidence from polar ice cores for the increase in atmospheric $\mathrm{CO}_{2}$ in the past two centuries. Nature, 315(6014), 45-47.

North Greenland Ice Core Project (NorthGRIP) members. 2004. High-resolution record of Northern Hemisphere climate extending into the last interglacial period. Nature, 431(7005), 111-228.

Nye, J.F. 1963. Correction factor for accumulation measured by the thickness of the annual layers in an ice sheet. J. Glaciol., 4(36), 785-788. 
Oeschger, H. 1988. Proceedings of the Symposium on Ice-Core Analysis held at the University of Bern, Switzerland, 30 March3 April 1987. Ann. Glaciol., 10.

Paterson, W.S.B. and G.K.C. Clarke. 1978. Comparison of theoretical and observed temperature profiles in Devon Island ice cap, Canada. Geophys. J. R. Astron. Soc., 55(3), 615-632.

Pearman, G.I., D. Etheridge, F. de Silva and P.J. Fraser. 1986. Evidence of changing concentrations of atmospheric $\mathrm{CO}_{2}, \mathrm{~N}_{2} \mathrm{O}$ and $\mathrm{CH}_{4}$ from air bubbles in Antarctic ice. Nature, 320(6059), 248-250.

Petit, J.R. and 18 others. 1999. Climate and atmospheric history of the past 420,000 years from the Vostok ice core, Antarctica. Nature, 399(6735), 429-436.

Rasmussen, S.O. and 15 others. 2006. A new Greenland ice core chronology for the last glacial termination. J. Geophys. Res., 111(D6), D06102. (10.1029/2005JD006079.)

Raynaud, D., J. Jouzel, J.M. Barnola, J. Chappellaz, R.J. Delmas and C. Lorius. 1993. The ice record of greenhouse gases. Science, 259(5097), 926-934.

Raynaud, D., J. Chappellaz, C. Ritz and P. Martinerie. 1997. Air content along the Greenland Ice Core Project core: a record of surface climatic parameters and elevation in central Greenland. J. Geophys. Res., 102(C12), 26,607-26,613.

Raynaud, D., J.M. Barnola, J. Chappellaz, T. Blunier, A. Indermuhle and B. Stauffer. 2000. The ice record of greenhouse gases: a view in the context of future changes. Quat. Sci. Rev., 19(1-5), 9-17.

Robin, G.deQ. 1955. Ice movement and temperature distribution in glaciers and ice sheets. J. Glaciol., 2(18), 523-532.

Saltzman, E.S., M. Aydin, W.J. De Bruyn, D.B. King and S.A. YvonLewis. 2004. Methyl bromide in preindustrial air: measurements from an Antarctic ice core. J. Geophys. Res., 109(D5), D05301. (10.1029/2003JD004157.)

Schmidt-Nielsen, K. 1987. Per Scholander, 1905-1980: a biographical memoir. Washington, DC, National Academy of Sciences. (Biographical Memoir 56.)

Scholander, P.F. and D.C. Nutt. 1960. Bubble pressure in Greenland icebergs. J. Glaciol., 3(28), 671-678.

Scholander, P.F., W. Flagg, R.J. Hock and L. Irving. 1953. Studies on the physiology of frozen plants and animals in the Arctic. J. Cell. Comp. Physiol., 42, Suppl. S1, 1-56.

Scholander, P.F., J.W. Kanwisher and D.C. Nutt. 1956. Gases in icebergs. Science, 123(3186), 104-105.

Scholander, P.F., E.A. Hemmingsen, L.K. Coachman and D.C. Nutt. 1961. Composition of gas bubbles in Greenland icebergs. J. Glaciol., 3(29), 813-822.

Scholander, P.F., W. Dansgaard, D.C. Nutt, H. de Vries, L.K. Coachman and E. Hemmingsen. 1962. Radio-carbon age and oxygen-18 content of Greenland icebergs. Medd. Grønl. 165(1).

Schwander, J. 1989. The transformation of snow to ice and the occlusion of gases. In Oeschger, H. and C.C. Langway, Jr, eds The environmental record in glaciers and ice sheets. Chichester, etc., Wiley, 53-67.

Schwander, J. and B. Stauffer. 1984. Age difference between polar ice and the air trapped in its bubbles. Nature, 311(5981), 43-47.

Schwander, J. and 6 others. 1993. The age of the air in the firn and ice at Summit, Greenland. J. Geophys. Res., 98(D2), 2831-2838.
Severinghaus, J.P. and E.J. Brook. 1999. Abrupt climate change at the end of the last glacial period inferred from trapped air in polar ice. Science, 286(5441), 930-934.

Severinghaus, J.P., T. Sowers, E.J. Brook, R.B. Alley and M.L. Bender. 1998. Timing of abrupt climate change at the end of the Younger Dryas interval from thermally fractionated gases in polar ice. Nature, 391(6663), 141-146.

Severinghaus, J.P., R. Beaudette, M.A. Headly, K. Taylor and E.J. Brook. 2009. Oxygen-18 of $\mathrm{O}_{2}$ records the impact of abrupt climate change on the terrestrial biosphere. Science, 324(5933), 1431-1434.

Shelesnyak, M.C. 1948a. Arctic Research Laboratory, Office of Naval Resesarch, Point Barrow, Alaska. Science, 107(2777), 283.

Shelesnyak, M.C. 1948b. The history of the Arctic Research Laboratory, Point Barrow, Alaska. Arctic, 1(2), 97-106.

Souchez, R., M. Lemmens and J. Chappellaz. 1995. Flow-induced mixing in the GRIP basal ice deduced from the $\mathrm{CO}_{2}$ and $\mathrm{CH}_{4}$ records. Geophys. Res. Lett., 22(1), 41-44.

Sowers, T., M. Bender and D. Raynaud. 1989. Elemental and isotopic composition of occluded $\mathrm{O}_{2}$ and $\mathrm{N}_{2}$ in polar ice. J. Geophys. Res., 94(D4), 5137-5150.

Sowers, T. and 10 others. 1997. An interlaboratory comparison of techniques for extracting and analyzing trapped gases in ice cores. J. Geophys. Res., 102(C12), 26,527-26,538.

Sowers, T., R.B. Alley and J. Jubenville. 2003. Ice core records of atmospheric $\mathrm{N}_{2} \mathrm{O}$ covering the last 106,000 years. Science, 301(5635), 945-948.

Spahni, R., J. Schwander, J. Flückiger, B. Stauffer, J. Chappellaz and D. Raynaud. 2003. The attenuation of fast atmospheric $\mathrm{CH}_{4}$ variations recorded in polar ice cores. J. Geophys. Res., 30(11), 1571. (10.1029/2003GL017093.)

Spencer, M.K., R.B. Alley and J.J. Fitzpatrick. 2006. Developing a bubble number-density paleoclimatic indicator for glacier ice. J. Glaciol., 52(178), 358-364.

Stauffer, B., H. Hofer, H. Oeschger, J. Schwander and U. Siegenthaler. 1984. Atmospheric $\mathrm{CO}_{2}$ concentration during the last glaciation. Ann. Glaciol., 5, 160-164.

Stauffer, B., A. Neftel, H. Oeschger and J. Schwander. 1985. $\mathrm{CO}_{2}$ concentration in air extracted from Greenland ice samples. In Langway, C.C., Jr, H. Oeschger and W. Dansgaard, eds. Greenland ice core: geophysics, geochemistry, and the environment. Washington, DC, American Geophysical Union, 85-89. (Geophysical Monograph 33.)

Svensson, A. and 7 others. 2005. Visual stratigraphy of the North Greenland Ice Core Project (NorthGRIP) ice core during the last glacial period. J. Geophys. Res., 110(D2), D02108. (10.1029/ 2004JD005134.)

Taylor, K.C. and 7 others. 1993. The 'flickering switch' of Late Pleistocene climate change. Nature, 361(6411), 432-436.

Taylor, K.C. and 13 others. 2004. Dating the Siple Dome (Antarctica) ice core by manual and computer interpretation of annual layering. J. Glaciol., 50(170), 453-461.

Voigt, D.E., R.B. Alley, S. Anandakrishnan and M.K. Spencer. 2003. Ice-core insights into the flow and shut-down of Ice Stream C, West Antarctica. Ann. Glaciol., 37, 123-128.

Wolff, E.W., ed. 2002. Papers from the International Symposium on Ice Cores and Climate, held at Kangerlussuaq, Greenland, 19-23 August 2001. Ann. Glaciol, 35. 